\title{
Pengaruh Waktu Pemupukan pada Dua Musim Tanam terhadap Karakter Wijen Sbr-1 dan Sbr-3 di Lahan Pasir Pantai
}

\author{
Dewi Ratna Nurhayati*1), Prapto Yudono' ${ }^{2)}$, Taryono ${ }^{2)}$, Eko Hanudin ${ }^{2)}$ \\ ${ }^{1)}$ Program Studi Agroteknologi, Fakultas Pertanian, Universitas Slamet Riyadi, Surakarta \\ ${ }^{2)}$ Fakultas Pertanian, Universitas Gadjah Mada \\ *Corresponding author: dewiratna2001@yahoo.com
}

\begin{abstract}
Sesame is recognized as healthy potential oil crops because can be used to control several diseases. Sesame can grow properly in light soil structure such as sandy coastal soil, however sandy soil is considered as unfertile one and therefore environmental friendly fertilizer application based on dung manure must be studied. The research toinvestigate the influence of application times of mixed fertilizer on the growth sesame in quality growth in coastal sandy soil both at rainy and dry seasons, therefore the experiment directly to the sandy field at the sandy coastal area of Keburuhan, Purworejo, Central Java. From the first stage, it could be said that the application of mixed fertilizer between chicken manure and inorganic fertilizer increasing tochlorophyll content, net assimilation rate, root volume sesame both in rainy and dry seasons.
\end{abstract}

Keywords: Chlorophyll content; Coastal area; Marginal land; Net assimilation rate

Cite this as: Nurhayati, D., Yudono, P., Taryono, \& Hanudin, E. 2018. Pengaruh Waktu Pemupukan pada Dua Musim Tanam terhadap Karakter Wijen Sbr-1 dan Sbr-3 di Lahan Pasir Pantai. Caraka Tani: Journal of Sustainable Agriculture. 33(1), 19-25. doi:http://dx.doi.org/10.20961/carakatani.v33i1.19442

\section{PENDAHULUAN}

Riset ini dilatarbelakangi oleh lahan pertanian yang semakin berkurang akibat alih fungsi dan lahan subur semakin berkurang. Sementara itu pasir pantai merupakan salah satu alternatif yang tergolong sebagai lahan marginal. Selama ini pasir pantai belum dimanfaatkan oleh masyarakat di sekitar pantai untuk kegiatan pertanian karena dinilai kurang layak sebagai media tanam. Namun demikian, pengolahan atau pemanfaatan lahan marginal atau lahan kurang potensial seperti pasir pantai untuk budidaya pertanian sebenarnya merupakan sebuah inovasi pemberdayaan sumber daya lahan termasuk pemberdayaan masyarakat di sekitar pantai mengingat lahan pertanian semakin berkurang.

Pada umumnya pemanfaatan lahan untuk budidaya tanaman masih terbatas, seperti jagung, kelapa dan pepaya. Pertimbangan pemberdayaan wijen (Sesamum indicum L.) diajukan dalam riset ini, karena tanaman ini adaptif dan tergolong diversified crop. Sebagai sumber minyak pangan banyak kegunaan dan berpotensi agroindustri dalam bidang bahan pangan, kue, penerangan, industri margarin, sabun, cat, produk parfum, maupun farmasi (bahan ramuan obat dan bahan/agen dispersi untuk membedakan macam insektisida). Negara pengekspor dan sekaligus pengimpor wijen baik dalam bentuk biji kering ataupun minyak adalah Indonesia. Namun seiring dengan peningkatan kualitas hidup masyarakat yang akan diikuti peningkatan pola dan kesadaran untuk hidup sehat, maka memberikan dampak peningkatan terhadap kebutuhan bahan pangan dan industri (salah satu berbahan dasar wijen), sehingga prospek pengembangan wijen memiliki potensi besar (Rachman,2007), karena Indonesia masih impor wijen di tahun 2007 (Ratnaningsih et al., 2007).

Tan (2001) menjelaskan pula bahwa mineral non humus merupakan hasil dari metabolisme organisme yang didalamnya mengandung berbagai komponen seperti karbohidrat, asam amino dan lipid. Hasil sintesis mikroba tanah yang berupa mineral humus yang terdiri dari asam humik, asam fulvik dan campuran bermasa tinggi merupakan bagian terbesar dari total bahan organik tanah. Menurut Varadachari et al. (1991) pada peran fraksi bahan organik adalah humus 
yang berinteraksi dengan pasir membentuk komplek humus pasir lebih kompak dan memberikan struktur tanah lebih baik bagi pertumbuhan tanaman. Mayoritas masyarakat di wilayah lahan pasir pantai memiliki ternak sapi, kambing maupun ayam.

Masyarakat memanfaatkan kotoran ternak tersebut terutama kotoran ayam untuk pupuk kandang. Seresah sisa hasil pertanian dan gulma yang tumbuh di lahan pasir pantai secara alami akan mengalami proses menjadi bahan organik. Sisa hasil pertanian umumnya diolah menjadi pupuk organik dengan proses biologi oleh mikroorganisme secara terpisah atau bersamasama dalam menguraikan bahan organik menjadi bahan semacam humus (Lingga, 2001). Humus mengakibatkan warna tanah lebih gelap sehingga penyerapan panas meningkat (Buckman dan Brady, 1982; Sanchez, 1976).

Wijen (Sesamum indicum L.) merupakan tanaman herba semusim, pertumbuhan tegak, tinggi tanaman berkisar antara $30-200 \mathrm{~cm}$, bercabang banyak namun ada juga yang tidak bercabang, batang tegak berkayu, berlekuk empat, beralur, berbuku dan berbulu halus, sedangkan daun tunggal menjulur panjang umumnya berselang-seling, dengan bentuk dan ukuran antara daun bawah, tengah dan atas berbeda. Wijen merupakan tanaman tahan kering, umur panen antara 2,5 - 5 bulan, selama pertumbuhan membutuhkan curah hujan antara $400-650 \mathrm{~mm}$ (Kaul dan Das, 1986).

Penggunaan varietas perlu disesuaikan dengan kondisi iklim dan pertanaman, mengingat setiap varietas mempunyai daya adaptasi berbeda terhadap kondisi setempat, serta mempunyai habitus dan umur berbeda. Kebutuhan benih untuk wijen monokultur $3-8 \mathrm{~kg} / \mathrm{ha}$, sedangkan untuk tumpang sari $2-3 \mathrm{~kg} / \mathrm{ha}$. Pada tahun 2011 telah dirilis benih wijen baru yakni Winas 1 dan Winas 2 yang sesuai untuk daerah tropik, dengan ketinggian 1 - 1.200 meter diatas permukaan laut (m dpl), sensitif terhadap suhu rendah, curah hujan tinggi, dan cuaca mendung terutama saat pembungaan. Suhu optimal yang dikehendaki selama pertumbuhan $25-30{ }^{\circ} \mathrm{C}$ dengan cahaya penuh. Wijen ini peka terhadap panjang hari dan termasuk tanaman hari pendek, dengan lama penyinaran sekitar $10 \mathrm{jam} / \mathrm{hari}$. Panjang hari sangat berpengaruh terhadap produksi, karena itu penundaan waktu tanam dari waktu optimal akan menurunkan produksi. Wijen mampu tumbuh baik dan berhasil pada semua jenis tanah, dapat tumbuh di lahan yang kurang subur maupun subur, terbaik pada tanah lempung berpasir yang subur dengan $\mathrm{pH}$ 5,5 - 8,0 dan tanah dangkal. Selain itu, wijen menghendaki drainase baik karena wijen tidak tahan tergenang, oleh karena itu pada tanah berat saluran drainase sangat diperlukan (Hariyono, 2005).

Sehubungan dengan persyaratan tumbuh, maka untuk memperoleh hasil tinggi perlu menggunakan kultivar unggul dan benih bermutu, persiapan lahan dan waktu tanam yang sesuai, populasi optimal, dosis pupuk sesuai anjuran, pengendalian organisme pengganggu tepat, dan pengairan sesuai kebutuhan tanaman. Penggunaan kultivar perlu disesuaikan dengan kondisi iklim dan pertanaman, beberapa kultivar wijen diantaranya Sumberrejo 1 (Sbr-1) dan Sumberrejo 3 (Sbr-3) (Rusim et al., 2007). Untuk itu perlu dipelajari karakter wijen yang ditanam di lahan pasir pantai pada musim tanam berbeda.

\section{METODE PENELITIAN}

Penelitian dengan percobaan dilakukan di lahan pasir pantai Keburuhan Kecamatan Purwodadi, Kabupaten Purworejo, pada dua musim tanam yaitu kemarau dan penghujan. Percobaan menggunakan rancangan petak terbagi (split plot) dengan 3 blok sebagai ulangan. Faktor yang diuji adalah waktu pemupukan dan kultivar. Waktu pemupukan meliputi 4 aras yaitu tanpa pemupukan sebagai kontrol, 5 hari sebelum tanam, saat tanam, dan 5 hari setelah tanam, sedangkan faktor kultivar terdiri atas kultivar Sumberrejo 1 (wijen putih) sebagai Sbr-1 dan kultivar Sumberrejo-3 (wijen hitam) sebagai Sbr-3.

\section{Penanaman}

Pada awal percobaan dilakukan pengolahan tanah menggunakan cangkul sedalam lapis olah tanah $(20 \mathrm{~cm})$ disertai dengan pembuatan petak sebagai satuan percobaan berupa Petakpetak percobaan dengan ukuran $2 \times 3 \mathrm{~m}$, benih ditanam dengan jarak 30 x $40 \mathrm{~cm}$. Pemupukan dilaksanakan sesuai dengan perlakuan, yaitu 5 hari sebelum tanam, saat tanam, dan 5 hari setelah tanam, dengan dosis pupuk kandang ayam $24,75 \mathrm{~g} /$ tanaman + anorganik $(1,45 \mathrm{~g} \mathrm{~N}$; $0,74 \mathrm{~g} \quad \mathrm{P} ; 1,25 \mathrm{~g} \mathrm{~K})$. Setelah benih berkecambah dilakukan penjarangan maupun pemeliharaan tanaman. Pengamatan karakter fisiologis diantaranya: 
a. Kandungan klorofil

Pengambilan contoh daun untuk pengukuran kandungan klorofil dilakukan pada saat tanaman mencapai tahapan vegetatif maksimum.

b. Kehijauan Daun

Pengukuran tingkat kehijauan daun yang dilakukan pada saat tanaman berumur 90 hari, dengan menggunakan alat SPAD.

c. Luas Daun

Luas daun diukur dengan menggunakan leaf area meter. Pengukuran luas daun dilakukan dengan menekan daun lebih dahulu dengan kaca, kemudian diukur dengan leaf area meter. Luas daun yang sesungguhnya diperoleh dengan cara mengalikan 2 dari hasil pembacaan leaf area meter (Fitter dan Hay, 1994).

d. Suhu Permukaan

Pengukuruan suhu permukaan daun dilakukan dengan menggunakan Li-cor Photosynthesis System pada saat tanaman mengalami tahapan vegetatif maksimum.

\section{Analisis Data}

Data yang diperoleh dianalisis menggunakan uji statistik analisis varians (anova). Apabila interaksi nyata maka selanjutnya diidentifikasi aras-aras dari setiap faktor yang berinteraksi, sedangkan apabila interaksinya tidak nyata, tetapi faktornya menunjukkan perbedaan maka dikenali aras yang menunjukkan perbedaan. Untuk mengidentifikasi keberadaan interaksi antar aras dan perbedaan antar aras dalam faktor digunakan uji lanjut LSD-Fisher (Least Significant Difference-Fisher) menggunakan $\alpha$ sebesar 5\%.

\section{HASIL DAN PEMBAHASAN}

\section{Luas Daun}

Dari pengamatan luas daun didapatkan informasi bahwa terdapat interaksi 3 faktor yaitu antara musim tanam, kultivar wijen, dan waktu pemupukan. Dengan kata lain, terdapat kerja sama antar faktor sehingga ketiga faktor tersebut dapat mempengaruhi luas daun. Luas daun terbesar diperoleh pada saat tanam musim kemarau untuk Sbr-1 dengan waktu pemupukan $\mathrm{H}+5$ atau perlakuan waktu pemupukan saat tanam. Tabel 1 menunjukkan bahwa terjadi interaksi pada musim tanam saat hujan yaitu antara Sbr-1 dan semua waktu pemupukan (kecuali kontrol). Pada musim tanam saat kemarau, interaksi justru terjadi pada Sbr-3 untuk kontrol dan penggunaan pemupukan 5 hari sebelum tanam.

Tabel 1. Luas Daun $\left(\mathrm{cm}^{2}\right)$ Kultivar Wijen Sbr-1 dan Sbr-3 yang Dipupuk pada Waktu yang Berbeda di Musim Tanam Hujan dan Kemarau

\begin{tabular}{lccc}
\hline \multicolumn{2}{c}{ Perlakuan } & \multicolumn{2}{c}{ Musim Tanam } \\
\hline \multicolumn{1}{c}{ Waktu Pemupukan } & Jenis Wijen & Hujan & Kemarau \\
\hline Tanpa Pemupukan & Sbr-1 & $132,10 \mathrm{i}$ & $136,98 \mathrm{i}$ \\
& Sbr-3 & $134,91 \mathrm{i}$ & $201,35 \mathrm{~cd}$ \\
H-5 hst & Sbr-1 & $161,28 \mathrm{gh}$ & $242,98 \mathrm{~b}$ \\
& Sbr-3 & $144,69 \mathrm{hi}$ & $175,19 \mathrm{efg}$ \\
Saat tanam & Sbr-1 & $166,16 \mathrm{~g}$ & $210,88 \mathrm{c}$ \\
& Sbr-3 & $175,07 \mathrm{efg}$ & $192,37 \mathrm{cde}$ \\
H+5 hst & Sbr-1 & $185,52 \mathrm{def}$ & $273,48 \mathrm{a}$ \\
& Sbr-3 & $172,86 \mathrm{fg}$ & $158,14 \mathrm{gh}$ \\
LSD 0,05 $=18,915$ & & &
\end{tabular}

Keterangan: rerata yang diikuti dengan huruf yang berbeda menunjukkan ada perbedaan nyata antar kombinasi perlakuan berdasarkan uji $\operatorname{LSD}(\alpha=0,05)$.

Penambahan pupuk menyebabkan luas daun semakin besar, sehingga diharapkan akan meningkatkan fotosintetis. Fotosintetis diharapkan akan meningkatkan pertumbuhan dan perkembangan tanaman, karena fotosintat yang dihasilkan lebih besar. Panjang, lebar, dan luas daun umumnya meningkat berangsur-angsur menurut ontogeni sampai ke suatu titik kemudian pada spesies tertentu menurun perlahan-lahan menurut ontogeni, sehingga daun terbesar terletak dekat dengan pusat tanaman. Berat dan luas maksimum daun suatu tanaman tercapai pada 
awal daur hidupnya, setelah itu meningkatnya berat dan luas daun sama, dengan menurunnya suatu status yang disebut sebagai luas daun kritis (Gardner et al., 1991). Maka dari itu, meskipun ada kecenderungan peningkatan luas daun dari tiap dosis pemberian pupuk $\mathrm{N}$, namun di saat tanaman memasuki fase generatif tidak ada beda nyata pada parameter luas daun. Hal ini disebabkan awal daur hidup tanaman sudah terlewati sehingga tidak ada lagi peningkatan yang signifikan pada luas daun.

Pengaruh pupuk kandang ayam yang memberikan hasil terbaik pada variabel pengamatan menyebabkan indeks panen juga meningkat. Hal tersebut sesuai dengan pendapat Sedjati (2005) bahwa unsur K sangat penting dalam proses pembentukan biji bersama unsur $\mathrm{P}$ yang mampu mengatur berbagai mekanisme dalam proses metabolik seperti fotosintesis, respirasi, pembentukan bunga, perkembangan akar, dan transportasi hara dari akar ke daun. Menurut Murbandono (2000), unsur hara yang terdapat dalam pupuk organik lambat tersedia untuk pertumbuhan tanaman, tetapi dengan penggunaan pupuk organik perbaikan tanah akan terus berlangsung.

\section{Kandungan Klorofil}

Pada pengamatan kandungan klorofil didapatkan informasi bahwa terdapat interaksi 3 faktor yaitu antara musim tanam, jenis wijen dan waktu pemupukan. Dengan kata lain, terdapat kerja sama antar faktor sehingga ketiga faktor tersebut dapat mempengaruhi klorofil total.

Tabel 2. Klorofil Total (mg-1) Bobot Segar Daun Kultivar Wijen Sbr-1 dan Sbr-3 yang Dipupuk pada Waktu yang Berbeda di Musim Tanam Hujan dan Kemarau

\begin{tabular}{lccc}
\hline \multicolumn{2}{c}{ Perlakuan } & \multicolumn{2}{c}{ MusimTanam } \\
\hline \multicolumn{1}{c}{ Waktu Pemupukan } & Kultivar Wijen & Hujan & Kemarau \\
\hline Tanpa Pemupukan & Sbr-1 & $0,89 \mathrm{c}$ & $0,91 \mathrm{bc}$ \\
& Sbr-3 & $0,98 \mathrm{ab}$ & $0,79 \mathrm{~d}$ \\
H-5 hst & Sbr-1 & $0,90 \mathrm{c}$ & $0,98 \mathrm{ab}$ \\
& Sbr-3 & $0,99 \mathrm{a}$ & $0,80 \mathrm{~d}$ \\
Saat tanam & Sbr-1 & $0,85 \mathrm{~cd}$ & $0,98 \mathrm{ab}$ \\
& Sbr-3 & $0,88 \mathrm{c}$ & $0,92 \mathrm{bc}$ \\
H+5 hst & Sbr-1 & $0,89 \mathrm{c}$ & $0,85 \mathrm{~cd}$ \\
& Sbr-3 & $0,88 \mathrm{c}$ & $0,98 \mathrm{ab}$
\end{tabular}

Keterangan: rerata yang diikuti dengan huruf yang berbeda menunjukkan ada perbedaan nyata antar kombinasi perlakuan berdasarkan uji $\operatorname{LSD}(\alpha=0,05)$.

Tabel 2 menunjukkan bahwa waktu pemupukan, musim tanam dan kultivar wijen berinteraksi terhadap klorofil total. Interaksi yang terjadi yaitu pada musim tanam hujan, kultivar Sbr-3 yang diberi pupuk 5 hari sebelum tanam maupun yang tidak dipupuk menyebabkan kadar klorofil total tertinggi, sedangkan pada musim tanam kemarau, interaksinya lebih beragam antar kultivar. Saat wijen tidak dipupuk dan saat pemupukan terjadi sebelum wijen ditanam serta saat pemupukan terjadi bersamaan dengan penanaman wijen, kandungan klorofil total kultivar Sbr-1 lebih tinggi daripada kultivar Sbr3. Akan tetapi, ketika pemupukan terjadi setelah penanaman, kandungan klorofil total kultivar Sbr3 lebih tinggi dari pada kultivar Sbr-1. Kedua kultivar wijen (Sbr-1 dan Sbr-3) memiliki respon yang berbeda terhadap waktu pemupukan sehingga menghasilkan kandungan klorofil yang berbeda dari kedua kutivar wijen tersebut

Unsur hara yang dihasilkan dari pemupukan berfungsi dalam proses pertumbuhan tanaman, sebagai komponen molekul enzim dan molekul klorofil, yang berperan dalam proses transfer energi di dalam sel dan dalam proses perombakan fotosintat menjadi molekul sederhana yang disusun kembali menjadi molekul bahan lain yang dikehendaki pada proses metabolisme sel tanaman (Spiertz \& Ellen, 1978). Fungsi N, P, dan $\mathrm{K}$ berkaitan erat dalam mendukung proses fotosintetis dan produksi fotosintat yang dihasilkan.

\section{Kehijauan Daun}

Dari pengamatan kehijauan daun tidak terdapat interaksi 3 faktor yaitu antara musim 
tanam, kultivar wijen, dan waktu pemupukan. Hanya terdapat kerja sama antara faktor kultivar wijen dan waktu pemupukan dalam mempengaruhi kehijauan daun. Tabel 3 menunjukkan bahwa terdapat interaksi antara kultivar wijen dan waktu pemupukan. Ketika tanaman tidak dipupuk ataupun dipupuk setelah waktu penanaman, kehijauan daun Sbr-1 sama dengan kehijauan daun Sbr-3. Akan tetapi, ketika pemupukan terjadi sebelum waktu penanaman ataupun saat penanaman, kehijauan daun Sbr-1 lebih tinggi daripada kehijauan daun Sbr-3.

Tabel 3. Kehijauan Daun (Unit SPAD) Kultivar Wijen Sbr-1 dan Sbr-3 yang Dipupuk pada Waktu yang Berbeda

\begin{tabular}{lcc}
\hline \multicolumn{1}{c}{ Perlakuan } & \multicolumn{2}{c}{ Kultivar wijen } \\
\hline \multicolumn{1}{c}{ Waktu Pemupukan } & Sbr-1 & Sbr-3 \\
\hline Tanpa Pemupukan & $3,53 \mathrm{abc}$ & $3,38 \mathrm{bcd}$ \\
H-5 hst & $3,63 \mathrm{a}$ & $3,31 \mathrm{~cd}$ \\
Saat tanam & $3,75 \mathrm{a}$ & $3,19 \mathrm{~d}$ \\
H+5 hst & $3,59 \mathrm{ab}$ & $3,66 \mathrm{a}$
\end{tabular}

$\mathrm{LSD}_{0,05}=0,237$

Keterangan: rerata yang diikuti dengan huruf yang berbeda menunjukkan ada perbedaan nyata antar kombinasi perlakuan berdasarkan uji LSD $(\alpha=0,05)$.

Pengamatan warna daun dilakukan pada saat tanaman memasuki fase vegetatif maksimal atau pada saat awal muncul bunga yaitu sekitar umur 50 - 60 hari setelah tanam. Pengamatan warna daun dilakukan dengan menggunakan munsell color chart untuk mengetahui nilai klorofil pada tanaman. Hasil pengamatan warna daun dengan menggunakan munsell colour chart menunjukkan adanya perbedaan tingkat kehijauan warna daun. Hal ini terjadi karena fungsi dari pemupukan selain merangsang pertumbuhan tanaman, juga memberikan warna hijau pada daun. Semakin gelap warna hijau daun pada tanaman menunjukkan semakin tinggi unsur nitrogen yang diserap tanaman. Hal ini didukung dari pernyataan Soepardi (1983) bahwa pada serealia, nitrogen akan memperbesar butir-butir dan persentase protein.

Daun berfungsi sebagai organ utama fotosintesis pada tumbuhan tingkat tinggi. Permukaan luar daun yang luas dan datar memungkinkannya menangkap cahaya semaksimal mungkin per satuan volume dan meminimalkan jarak yang harus ditempuh oleh $\mathrm{CO}_{2}$ dari permukaan daun ke kloroplas, yaitu jarak sekitar 0,1 mm pada daun-daun kebanyakan tanaman budidaya (Gardner et al., 1991). Salah satu unsur pupuk yakni nitrogen berperan merangsang pertumbuhan di atas tanah dan memberikan warna hijau pada daun. Gardner et al.
(1991) menyatakan bahwa agar pemanfaatan radiasi matahari oleh tanaman budidaya dapat dilakukan secara efisien, maka penyerapan radiasi tersebut harus sebagian oleh jaringan fotosintesisnya yang hijau. Untuk mendapatkan warna hijau yang tepat pada daun wijen, maka pemberian pupuk menjadi cara yang efektif. Fotosintesis menjadi satu-satunya sumber energi bagi kehidupan tanaman selama pertumbuhan. Kandungan klorofil yang ada di dalam daun menunjukkan status hara $\mathrm{N}$ pada tanaman.

\section{Suhu Daun}

Hasil yang diperoleh terdapat interaksi 2 faktor yaitu antara kultivar wijen dan waktu pemupukan. Sementara itu, faktor musim tanam mempengaruhi suhu daun secara independen (tidak bergantung) dengan kultivar wijen dan waktu pemupukan. Faktor musim mempengaruhi suhu daun tanaman, dengan musim kemarau menyebabkan suhu daun lebih tinggi daripada musim hujan. Sementara itu, interaksi terjadi antara waktu pemupukan dan kultivar wijen. Suhu daun pada Sbr-3 lebih tinggi daripada Sbr-1 untuk semua waktu pemupukan, termasuk kontrol. Kecuali pada saat pupuk diberikan 5 hari setelah tanam, baik Sbr-1 maupun Sbr-3 tidak saling berinteraksi, terlihat dari suhu daun yang cenderung tetap (Gambar 1; Tabel 4). 
Tabel 4. Suhu Daun $\left({ }^{\circ} \mathrm{C}\right)$ pada Kultivar Wijen Sbr-1 dan Sbr-3 yang Dipupuk pada Waktu yang Berbeda

\begin{tabular}{lcc}
\hline \multicolumn{1}{c}{ Perlakuan } & Kultivar Wijen \\
\hline \multicolumn{1}{c}{ Waktu Pemupukan } & Sbr-1 & Sbr-3 \\
\hline Tanpa Pemupukan & $32,41 \mathrm{c}$ & $33,49 \mathrm{a}$ \\
H-5 hst & $30,99 \mathrm{~d}$ & $32,87 \mathrm{~b}$ \\
Saat tanam & $31,19 \mathrm{~d}$ & $32,08 \mathrm{c}$ \\
$\mathrm{H}+5$ hst & $32,11 \mathrm{c}$ & $32,20 \mathrm{c}$ \\
$\mathrm{LSD}_{0,05}=0,4087$ & &
\end{tabular}

Keterangan: $\quad$ rerata yang diikuti dengan huruf yang berbeda menunjukkan ada perbedaan nyata antar kombinasi perlakuan berdasarkan uji LSD $(\alpha=0,05)$.

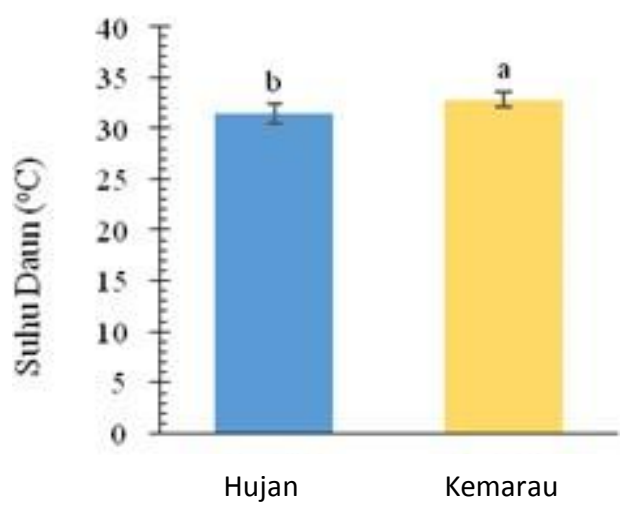

Gambar 1. Pengaruh Musim Tanam terhadap Suhu Daun.

Huruf yang sama tidak berbeda nyata berdasarkan uji LSD-Fisher $(\alpha=0,05)$.

Unsur hara makro (N, P dan $\mathrm{K}$ ) dan mikro merupakan unsur utama bagi pertumbuhan tanaman, apabila tanaman kekurangan unsur tersebut maka pertumbuhan akan terhambat. Menurut Lingga dan Marsono, (2000) agar mencapai pertumbuhan yang maksimal, pemakaian pupuk organik hendaknya diikuti dengan pemberian pupuk anorganik sehingga kedua pupuk dapat saling menyediakan unsur hara bagi tanaman untuk mencapai pertumbuhan yang maksimal. Selain itu keduanya saling menyediakan hara bagi kebutuhan tanaman dan terciptanya tanah yang lebih subur dan struktur yang gembur. Tanaman yang kekurangan unsur hara akan mengalami penurunan produktifitas dan pertumbuhannya menjadi terhambat. Pupuk organik juga mempunyai manfaat dalam memberikan media bagi kehidupan mikroorganisme menguntungkan bagi kesuburan tanah dan mengurangi porositas pada tanah pasir dan membantu aerasi pada tanah lempung. Pemakaian pupuk organik sangat disarankan, khususnya bahan-bahan organik yang terkandung didalam pupuk organik tersebut.

\section{KESIMPULAN}

Pemberian pupuk berupa pupuk kandang ayam pada takaran $24,75 \mathrm{~g}$ dan pupuk anorganik NPK: $1,45 \mathrm{~g} ; \mathrm{N}: 0,74 \mathrm{~g}$; P: $1,25 \mathrm{~g} \mathrm{~K} /$ tanaman yang diberikan pada saat tanam di musim kemarau, memberikan pengaruh terbaik terhadap karakter pertumbuhan wijen Sbr-1 dan Sbr-3 yang ditanam di Lahan Pasir Pantai.

\section{DAFTAR PUSTAKA}

Buckman, H.O., \& Brady. 1982. Ilmu Tanah. Penerjemah: Soegiman. Jakarta: Bharata Karya Aksara.

Fitter,A.H., \& Hay, R.K.M. 1981. Environment Physiologyof Plant. Academic Press, London. $367 \mathrm{p}$.

Gardner, F.P., Pearce, R.B., \& Mitchell, R.L. 1991. Physiology of Crop Plants. Diterjemahkan oleh H.Susilo. Jakarta. Universitas Indonesia Press.

Hariyono. 2005. Pengembangan Wijen di Lahan Sawah Sesudah Padi (MK-1 dan 2). Studi 
Kasus Kecamatan Baki, Kabupaten Sukoharjo, Jawa Tengah. Laporan hasil kunjungan ke kabupaten Sukoharjo.

Kaul, A.K., \& Das, M.L. 1986. Oilseeds in Bangladesh. Bangladesh-Canada Agric. Sector Team, Ministry of Agric. Gov. of the People's Rep. of Bangladesh, Dhaka.185 p.

Lingga \& Marsono. 2000. Pengaruh penggunaan pupuk organik dan anorganik terhadap pertumbuhan dan produksi bawang merah kultivar Palu. Jurnal Hortikultura.

Lingga, P. 2001. Petunjuk Penggunaan Pupuk. Penebar Swadaya. Jakarta. 80. Hal

Rachman, AH. 2007. Status wijen (Sesamum indicum L.) di dalam dan luar negeri, Prosiding seminar memacu pengembangan wijen untuk mendukung agroindustry. Puslitbangbun. Bogor, hlm. 1-5.

Ratnaningsih, E., Rahayu, M, \& Hariyono, B. 2007. Potensi Pengembangan Tanaman Wijen (Sesamum indicum L.) di Lahan Kering Kabupaten Gunung Kidul Daerah Istimewa Yogyakarta. Prosiding Seminar Memacu Pengembangan Wijen Untuk Mendukung Agroindustri, Pusat Penelitian dan Pengembangan Perkebunan.
Rusim, Mardjono, Hariyono, B., Romli, M., Soenardi, Sudarmo, H., \& Suprijono. 2007. Optimasi Dosis Pupuk N Pada Galur Unggul Baru Wijen Untuk Menunjang Pelepasan Varietas. Laporan Hasil Penelitian 2005. Balittas, Malang. $16 \mathrm{p}$

Sanchez, P.A. 1976. Sifat dan Pengelolaan Tanah Tropika. Terjemahan J.T. Jayadinata. 1992. ITB. Bandung Senawi, 1999. Evaluasi dan Tata Guna Lahan Hutan. Fakultas Kehutanan.

Soepardi, G. 1988. Sifat dan Ciri Tanah. Departemen Institut Per- tanian Bogor. 591p Dalam Skripsi Sri, Y. 2002. Kajian dosis dan frekuensi pupuk nitrogen pada pertumbuhan dan hasil jagung (Zea mays L.). Yogyakarta. $57 \mathrm{~h}$

Suwardi \& R. Efendi. 2009. Efisiensi Penggunaan Pupuk N Pada Jagung Komposit Menggunakan Bagan Warna Daun. ., Diakses 15 Mei 2013

Tan, K.H. 2001. Kimia Tanah. Penerbit UGM Press. Yogyakarta.

Varadachari, C., Mondal, A.H., \& Ghosh, K. 1991. Some Aspects of Clay-Humus Complexation: Effect of Exchangable Cation and Lattice Charge. Soil Sci. 15(3), 220-227. 